\title{
Economic Situation in Agriculture and Challenges of Crop Farming Development
}

\author{
Elena V. Voloshenko \\ Ksenia Yu. Voloshenko* \\ Immanuel Kant Baltic Federal University, Russian Federation \\ *Corresponding Email: KVoloshenko@kantiana.ru
}

Doi:10.5901/mjss.2015.v6n6s7p295

\begin{abstract}
The article deals with the development of agriculture in the Kaliningrad region in 2000-2014. It analyses changes of procedural and institutional business patterns, the dynamics of key performance indicators in crop and livestock farming, and the state of food reserve, agricultural machinery supply and specific characteristics of soil modification in the region. The difficulties of rendering support to agricultural manufacturers in current economic environment are brought to light. Primary trends and key factors of sustainable development of agriculture in the region are defined in the light of current primary trends in global and Russian economies and changes in geopolitical environment.
\end{abstract}

Keywords: agriculture, trends, primary factors, long-term development, geopolitical environment

\section{Introduction}

Providing support to the farming industry development in the Kaliningrad region is now becoming ever more relevant as long as an array of sanctions against Russia was imposed in 2014 and expanded in 2015, with an embargo on a wide range of food imported from other countries. In this context, the study of new trends and factors of long-term development of agriculture in the region and as well as the current trends in the world and Russian economies are of particular importance. Special attention should be given to crop farming - a significant branch of the agricultural industry, which provides $70 \%$ of food consumed by the population.

\section{Forms of Management}

The structure of farming enterprises and organizations of the Kaliningrad region is formed by such types of management as farms, private households, peasant (farmer) households (PFH) and private entrepreneurs. In 2015, there are 1,295 enterprises and organizations (54.9\% are farms, 39.2\% are private households, and $5.9 \%$ are PFHs and private entrepreneurs) in the farming industry of the Kaliningrad region, which accounts to $2.4 \%$ of all enterprises in the region. It is a 2.4-fold decrease ${ }^{1}$ compared with last year and a 2.8-fold decrease compared 2000 , and the year 2004 witnessed their maximum number -3776 enterprises.

The period under analysis is characterized by a gradual change in the importance of private households and production scale-up, which resulted in increase of agricultural organizations number. Number of PFH and private entrepreneurs participating in production is relatively constant and do not exceed $7 \%$ at different time periods.

Small share of PHP and private entrepreneurs in the region is caused by several reasons. Firstly, the provision of plots of land for farming is complicated in many aspects. Secondly, the government support in this sphere is lacking efficiency, there are no special measures on encouragement of small agribusiness products output. Thirdly, the level of cooperation in agriculture is quite low and the legal status of farming enterprises is not defined yet. It is worth mentioning, that there is no cooperation between these enterprises and retail trade networks. All these factors hinder the development of PHP and farming enterprises in the country, which results in low agriproductivity index.

\footnotetext{
${ }^{1}$ The decrease in number of enterprises is due to activities carried out by the Department of the Federal Tax Service for the Kaliningrad region According to Art. 21.1 of the Federal law from 08.08.2001 of N 129-Federal "About the exclusion of legal entities, having stopped their activity from the Unified State Register of Legal Entities". The enterprises which have not registered (re-registration) with the Tax services bodies are excluded as well.
} 


\section{Indexes of Agricultural Industry Development}

Agriculture development conditions and factors in the Kaliningrad region differ greatly from those in the majority of the RF entities and are rather similar to ones in the Baltic Sea countries. Climatic parameters of the region (longer vegetation season and mild winters), economic factors (developed traffic network and multiple cities) and the existence of business management centers in village areas give the Kaliningrad region an advantage over Non-Chernozem Zone (Non-Black Earth) of the Russian Federation.

On the other hand, there are a number of development problems in the agricultural industry of the region. The mechanism of Special Economic Zone (SEZ) - 1996 (On the Special Economic Zone in the Kaliningrad area, 1996), which was effectively on up to 2006, made regional agricultural producers face the fierce completion with importers, whose production is carried out in more favorable conditions with government support making their product less expensive. The fact that food market is open and food import is free of duty worsened the impact of economic downturn in agriculture of the Kaliningrad region, especially in crop farming and livestock. The output of gross agricultural product in all categories of farmsteads had been decreasing since 2000 up to 2007, and it began to increase in 2008 only. It results from the application of special measures and governmental programs on the support to the agricultural industry. In 2014 the production output grew 1.5 times as compared to 2000 of which crop farming output -1.7 times and livestock -1.3 times (Fig. 1).

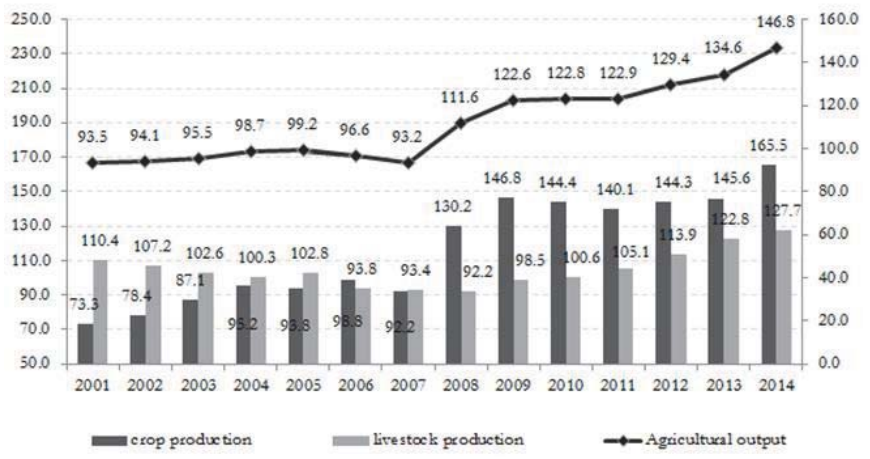

Figure 1. Indexes of agricultural products output (in all categories of farmsteads, prices current for the year stated; 2000100\%), 2000-2014

Source: calculated on the basis of (Federal State Statistics Service in the Kaliningrad region, 2010, 2015)

Compared with 2000, there is a decrease of crop farming and livestock proportion in the gross agricultural product. The proportion of livestock in gross agricultural output in 2014 dropped to $45.9 \%$ (it was 54.4 in 2000). It results from the changes in the structure of agricultural production and support to non-traditional for the Kaliningrad region agricultural products. The monitoring period witnessed the reorientation of agriculture towards new agricultural products and raw materials demanded on internal and external markets (rapeseeds, for instance) due to the advantageous geographical location of the region and specialization of regional agricultural industry. Some conjectural fluctuations in the output of such products as cereals, vegetables and meat (in slaughter weight) are rather visible (Fig. 2). 


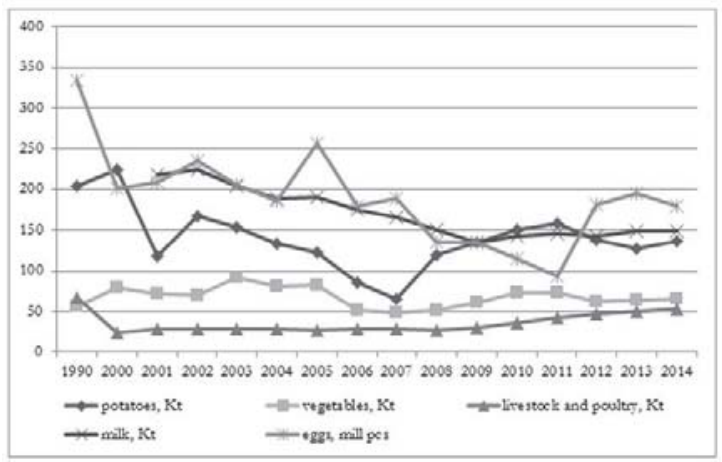

Figure 2. Dynamics of basic agricultural products output (in all categories of farmsteads) in the Kaliningrad region Source: calculated on the basis of (Federal State Statistics Service in the Kaliningrad region, 2005-2015)

Crop farming

In 2014, cropped area in all categories of farmsteads was 222, 2 thousand hectares, which is by 39.9 thousand hectares more than in 2000. The structure of the cropped are: $50.6 \%$ - cereals and grain legume crops, $15.0 \%$ - industrial crops культуры, $4.8 \%$ - potato and cucurbits crops, $29.5 \%$ - fodder crops. Thus, the structure of cropped area had not experienced any considerable changes within the monitoring period.

At the same time, the area of feeding crops, potato and cucurbit crops has decreased as compared to 1990 and 2000. It is worth mentioning, that the Kaliningrad region presents one of the highest levels of yields in the Northwestern Federal District of Russia as compared to average figures in Russia (cereals and grain legume crops - 39.1 hundredweights/ha, potato - 166.0 hundredweights/ha, vegetables- 268.7 hundredweights/ha) (IIAISS, 2014). As compared to Baltic Sea countries this index is lower than that of Germany, Denmark and Sweden (through the example of cereals and potato yields) (Fig. 3)
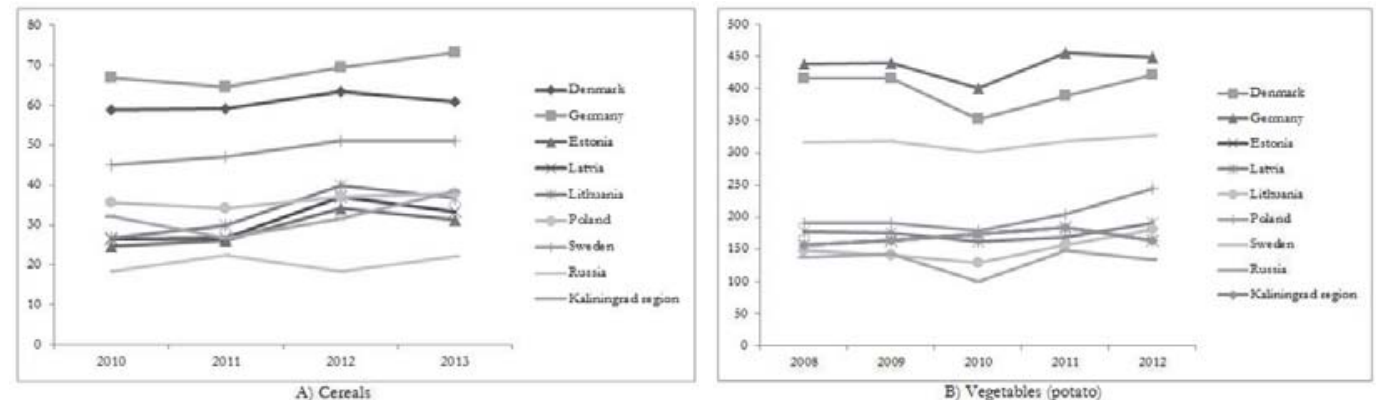

Figure 3. Yields of agricultural crops in the Baltic Sea region countries, hundredweights/ha (of harvested land) Source: Rosstat, Eurostat, (Federal State Statistics Service in the Kaliningrad region, 2013)

The increase in crops yield in the Kaliningrad region is achieved by the enlarged use of mineral and organic fertilizers and enlarged proportion of the fertilized fields in the crop area. As compared to the average figures in Russia and the Baltic Sea region countries, the Kaliningrad region has a high index of fertilizers use and comes after Germany and Poland in the list (Fig. 4).

The soil of crop area in the Kaliningrad region is characterized by low level of cobalt, molybdenum and zinc. Half of the area is poor in copper and boracium. All these justify the permanent and reasonable use of fertilizers which boosts the crop productivity of the region. However, there are some difficulties in fertilizers supply of the region - fertilizers are bought in Russia, but payments are usually performed in foreign currency due to the fact that fertilizers in Russia are produced mainly for export. 


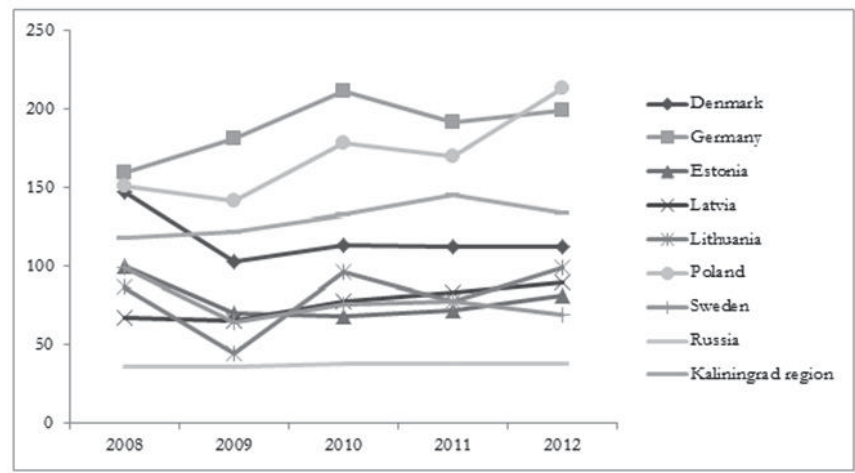

Figure 4. Use of mineral fertilizers in the Baltic Sea region countries, hundredweights/ha (in 100\% soil nutrients per 1 ha of cropped area)

Source: Rosstat, Eurostat, EMISS (Federal State Statistics Service in the Kaliningrad region, 2013)

The expenditures of the crop farming are mainly material costs (50-60 \%) including costs of seeds and planting stock, mineral and organic fertilizers, crop protection biocides, fuel and energy and third-parties services. Seeds and planting stock are purchased abroad (70 \%), which poses some constraints in the condition of sanctions imposed against Russia and decrease of ruble rate.

\section{Technical Equipment and Irrigation}

\subsection{Agricultural machinery}

Success of agricultural production depends on the material and technical base of agricultural manufacturers. 2000-2010 witnessed some growth in the level of technical equipment in the region (number of agricultural machineries per 1 ha of arable land or cultivated area). For instance, the number of tractors per 1000 ha of arable land in the Kaliningrad region has reached the highest values, which is on average among the top values in Russia but still signifies the lack of agricultural technical equipment in the region and growing gap between the technical bases of developed countries. It is proved by the decrease in absolute value of all types of machinery except for cutter-rowers (their number grew 4 times). As compared to 2000 the supply of agricultural machinery accounted only for $20-25 \%$. Moreover, generating capacity of the region had decreased in 1.7 times within 2000-2014². This results in enlarged load of arable land and cropped areas which signifies poor effectiveness of farming operations.

\subsection{Irrigation}

Due to weather and climatic conditions in the Kaliningrad region intensive agricultural production can be run without any melioration activities. Good irrigation state of arable lands is in 90-95 \% of territories with more than 596 thousand ha are drained by subsoil drainage and open canals. According to irrigation survey conducted in spring (2013) out of all the drained land of the Kaliningrad region only 41020 ha are in good condition , 369359 ha are in satisfactory condition and the condition of 183430 ha (31 \% of all arable lands) is unsatisfactory. Due to malfunction of irrigation system many crops die from rotting and winter-killing. It is important that $94 \%$ of all agricultural areas are drained artificially. It means that if not drained these areas will become marshy. Thus, irrigation system of the region does not cope with the excessive soil wetting. In 2015, under the governmental program "Land fertility" 8.8 billion rubles are to be spent on irrigation, but the allocated money is not enough, ta king into consideration the necessity to carry out melioration activities and restore the whole system (Federal State Statistics Service, 2010). 


\section{Conclusion}

The conducted analysis of the agricultural industry in the Kaliningrad region reveals its instability and demonstrates the gap between the current pace and indicators of economic development and those of the end of XX century. Indexes of agricultural industry development, fodder supply and state of material and technical base, level of technical equipment and development of technologies are still very low, which signifies the deterioration in cattle productivity and agricultural manufacturers' effectiveness. The problem of crop farming development is of great relevance, because the current state of its production is not enough for food self-sufficiency of the region (except for the potato) and is sometimes defined as critically low.

\section{References}

Federal State Statistics Service in the Kaliningrad region (2005). The Kaliningrad region in figures. A statistical report. Kaliningrad. Federal State Statistics Service in the Kaliningrad region (2007). The results of the survey on the production of milk in private farms of the rural population. Kaliningrad.

Federal State Statistics Service in the Kaliningrad region (2008). The Kaliningrad region in figures. A statistical report. Kaliningrad. Federal State Statistics Service in the Kaliningrad region (2009). The Kaliningrad region in figures. A statistical report. Kaliningrad. Federal State Statistics Service in the Kaliningrad region (2010). The Kaliningrad region in figures. A statistical report. Kaliningrad. Federal State Statistics Service in the Kaliningrad region (2010). Agriculture of the Kaliningrad region. A statistical report. Kaliningrad. Federal State Statistics Service in the Kaliningrad region (2011). The Kaliningrad region in figures. A statistical report. Kaliningrad. Federal State Statistics Service in the Kaliningrad region (2012). The Kaliningrad region in figures. A statistical report. Kaliningrad.

Federal State Statistics Service in the Kaliningrad region (2012). Social and economic situation of the Kaliningrad region in 2011. Kaliningrad.

Federal State Statistics Service in the Kaliningrad region (2013). Agriculture of the Kaliningrad region. A statistical report. Kaliningrad. Federal State Statistics Service in the Kaliningrad region (2015). The Kaliningrad region in figures. A statistical report. Kaliningrad. In the Kaliningrad region reconstruct 41 objects reclamation URL: http://www.mcx.ru/news/news/show/34914.174.htm (date of treatment: 03/07/2015)

On the Special Economic Zone in the Kaliningrad area: the Federal Law of January 22, 1996 №13-FZ (as amended) 